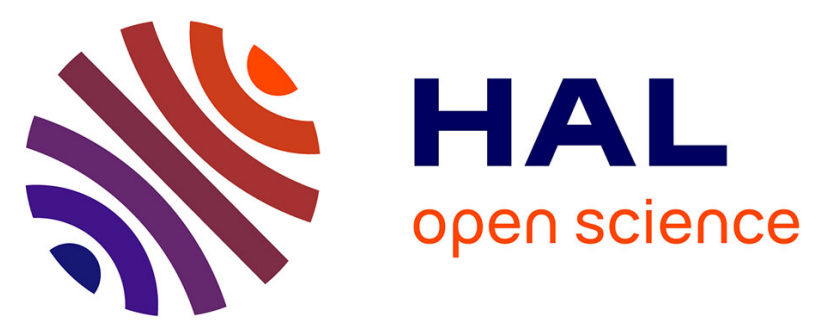

\title{
Pinus cembra L. (arolla pine), a common tree in the inner French Alps since the eõvmvarly Holocene and above the present tree line: a synthesis based on charcoal data from soils and travertines
}

\author{
Adam A Ali, Christopher Carcaillet, Brigitte Talon, Paul Roiron, \\ Jean-Frédéric Terral
}

\section{To cite this version:}

Adam A Ali, Christopher Carcaillet, Brigitte Talon, Paul Roiron, Jean-Frédéric Terral. Pinus cembra L. (arolla pine), a common tree in the inner French Alps since the eõvmvarly Holocene and above the present tree line: a synthesis based on charcoal data from soils and travertines. Journal of Biogeography, 2005, 32 (9), pp.1659 - 1669. 10.1111/j.1365-2699.2005.01308.x . hal-01791219

\section{HAL Id: hal-01791219 \\ https://hal-amu.archives-ouvertes.fr/hal-01791219}

Submitted on 12 Mar 2019

HAL is a multi-disciplinary open access archive for the deposit and dissemination of scientific research documents, whether they are published or not. The documents may come from teaching and research institutions in France or abroad, or from public or private research centers.
L'archive ouverte pluridisciplinaire HAL, est destinée au dépôt et à la diffusion de documents scientifiques de niveau recherche, publiés ou non, émanant des établissements d'enseignement et de recherche français ou étrangers, des laboratoires publics ou privés. 


\section{Pinus cembra L. (arolla pine), a common tree in the inner French Alps since the early Holocene and above the present tree line: a synthesis based on charcoal data from soils and travertines}

Adam A. Ali ${ }^{1 \star}$, Christopher Carcaillet ${ }^{1}$, Brigitte Talon ${ }^{2}$, Paul Roiron ${ }^{1}$ and Jean-Frédéric Terral ${ }^{1}$

${ }^{1}$ Centre de Bio-Archéologie et d'Ecologie (UMR 5059 CNRS/U. Montpellier 2/EPHE), Institut de Botanique, Montpellier, France and ${ }^{2}$ Institut Méditerranéen d'Ecologie et de Paléoécologie (UMR 6116 CNRS), Université de Aix-Marseille 3, Faculté des Sciences et Techniques de St-Jérôme, Marseille Cedex, France
${ }^{*}$ Correspondence: Adam A. Ali, Centre de BioArchéologie et d'Ecologie (UMR 5059 CNRS/U. Montpellier 2/EPHE), Institut de Botanique, 163 rue Auguste Broussonet, F-34090 Montpellier, France.

E-mail: ali@univ-montp2.fr

\begin{abstract}
Aim In this study, charcoal-based data for Pinus cembra L. (arolla pine) were gathered from soil and travertine sequences in order to reconstruct its historical biogeography at the landscape level in the inner western Alps during the Holocene.

Location The study sites are located between 1700 and $2990 \mathrm{~m}$ a.s.l., in the southern (Queyras Massif and Ubaye Valley) and the northern (Maurienne Valley) parts of the inner French Alps.

Methods Charcoal fragments were extracted from sediments by water sieving, using meshes of 5, 2, 0.8 and $0.4 \mathrm{~mm}$. The charcoal mass of $P$. cembra was determined in each charcoal assemblage. Accelerator mass spectrometry and conventional ${ }^{14} \mathrm{C}$ measurements were used to date the fragments.

Results Supported by $40{ }^{14} \mathrm{C}$ datings, the fragments show that, over $2000 \mathrm{~m}$ a.s.l., P. cembra accounts for around $40 \%$ (mean value) of identified fragments. Data reveal that arolla pine once extended between 260 and $375 \mathrm{~m}$ above the presentday local tree lines. It was established in the southern and the northern French Alps from at least c. 9000 and $6000 \mathrm{cal} \mathrm{yr} \mathrm{BP,} \mathrm{respectively.}$

Main conclusions While present-day populations of $P$. cembra are very fragmented in the inner French Alps, charcoal records indicate large past occurrences of this tree since the early Holocene. Human disturbance since the Neolithic seems to be the main reason for the regression of the arolla pine woodlands. On the south-facing slopes of the study sites, currently deforested, this species extended up to $2800 \mathrm{~m}$ a.s.l. In the northern areas, charcoal records of the $P$. cembra expansion are consistent with the regional pollen archives, but in the southern massifs charcoal records indicate its presence $c .2600$ years earlier than other palaeobotanical studies suggest. This discrepancy highlights the necessity to crosscheck data using several different proxies in order to assess the validity of conclusions regarding tree development in space and time.
\end{abstract}

\section{Keywords}

Biogeography, charcoal, fire, French Alps, Holocene, Pinus cembra, soil, travertine.

\section{INTRODUCTION}

Pinus cembra L. (arolla pine) is today distributed in mountainous regions from the Carpathian Mountains and Transylvania to the French Alps (Polunin \& Walters, 1986). Arolla pine is a key species at high altitudes, and its regeneration depends on the European nutcracker, Nucifraga caryocatactes L. (Mattes, 1994; Camaret et al., 1998). This bird, which exploits diverse vegetation 'pockets' for feeding and removes seeds, assists in seed dispersal, especially in rocky open patches 
that are sparsely covered with dwarf woody shrubs in windexposed sites (Crocq, 1990). Consequently, the regeneration success of the arolla pine is spatially limited in comparison with that of other sympatric competitive coniferous species, such as Pinus uncinata Mill. (mountain pine), Larix decidua Mill. (larch) and Picea abies (L.) Karst. (spruce), that have wind-dispersed seeds. The present-day distribution of Pinus cembra is highly fragmented in the inner French Alps, where it forms homogeneous or mixed woodlands in association with $L$. decidua, $P$. uncinata and $P$. abies. The French forest inventory administration (Inventaire Forestier National) observed that $P$. cembra forests currently cover 1513 ha, whereas L. decidua and P. uncinata cover 90,140 and 16,650 ha, respectively (http://www.ifn.fr/), highlighting the scarcity of arolla woodlands. P. cembra essentially grows on the northfacing slopes of valleys, while the south-facing slopes are generally deforested, with large pasture areas devoted to agropastoral uses (Contini \& Lavarello, 1982). However, with the collapse of human activities in mountain regions since c. AD 1950, the abandoned lands above $2000 \mathrm{~m}$ a.s.l. have been progressively colonized by larch and spruce stands with scattered arolla individuals (Didier, 2001; Motta \& Nola, 2001).

To date, the biogeography of $P$. cembra has been investigated principally using pollen analyses. Pinus cembra has been present in the central Alps since at least 13,000 cal yr вР (Burga, 1988; Heiri et al., 2003). Pollen-based studies suggest that it progressively diffused from central to western areas (Burga, 1988), establishing at c. $9500 \mathrm{cal} \mathrm{yr} \mathrm{в} \mathrm{в} \mathrm{in} \mathrm{the} \mathrm{northern}$ French Alps (Wegmüller, 1977; David, 1995) and at c. $6400 \mathrm{cal}$ yr BP in the southern massifs (de Beaulieu, 1977; Coûteaux, 1982, 1984; Fauquette \& Talon, 1995; Nakagawa et al., 2000). However, it has been shown in alpine-tundra zones that pollen analyses alone cannot provide precise reconstructions of plant occurrence and biogeography (Payette \& Gagnon, 1985; Ritchie, 1995; Kullman, 1996, 2001, 2002; Carcaillet et al., 1998; Odgaard, 2001): pollen records must be coupled with studies of plant macrofossils in order to decipher past highelevation vegetation composition and structure (Jackson et al., 1997; Birks \& Birks, 2000; Ali et al., 2003; Birks, 2003). This is partly because of differences between species in the altitudinal variability of pollen production, and partly because the winddispersal of pollen can give misleading indications about species distribution, especially for Pinus, Betula and Alnus species (Birks \& Birks, 2000; Odgaard, 2001; Kullman, 2002). Moreover, woodland from high elevations can grow in the alpine tundra as dispersed and isolated trees or as tree islands (Holtmeier \& Broll, 1992), with inevitable reductions in pollen production (Moe, 1998) and developing vegetative reproduction processes (Tranquillini, 1979; Arquillière, 1986).

In the present study, we report data gathered from the analysis of charcoal fragments preserved in travertine and natural soil located in southern (Aigue Agnelle, Guil and upper Ubaye valleys) and northern (upper Maurienne Valley) parts of the inner French Alps. Travertine sequences are natural calcareous deposits resulting from both physiochemical and biological processes related to the bicarbonate saturation of water (Magnin et al., 1991; Geurts \& Watelet, 1997; Guendon et al., 2003). Mountain travertines frequently enclose charcoal remains in detrital layers (Ali et al., 2002, 2004, 2005).

According to studies of charcoal transportation during and after fires, fragments $>0.4 \mathrm{~mm}$ are not mass-transported by air by more than a few metres from the sources of ignition (Clark et al., 1998; Blackford, 2000; Ohlson \& Tryterud, 2000; Lynch et al., 2004), and thus represent reliable palaeobotanical proxies to reconstruct past vegetation composition and structure with high spatial resolution. The present data, based on charcoal $>0.4 \mathrm{~mm}$ and supported by radiocarbon datings, allow the altitudinal and geographical distribution of $P$. cembra in the inner French Alps during the Holocene to be reconstructed.

\section{STUDY AREAS}

The valleys of Aigue Agnelle $\left(44^{\circ} 44^{\prime} \mathrm{N}, 6^{\circ} 53^{\prime} \mathrm{E}\right)$ and Guil $\left(44^{\circ} 44^{\prime} \mathrm{N}, 6^{\circ} 58^{\prime} \mathrm{E}\right)$ are located $5 \mathrm{~km}$ apart in the Queyras area (Fig. 1), along the French/Italian border. The present-day climate in the area has montane mediterranean-continental characteristics, with a precipitation minimum in summer (July: $50 \mathrm{~mm}$ ) and a maximum in late spring (June: $100 \mathrm{~mm}$ ). The climatic data were obtained from the weather station of SaintVéran (2125 m a.s.l.) in a neighbouring valley. Mean monthly

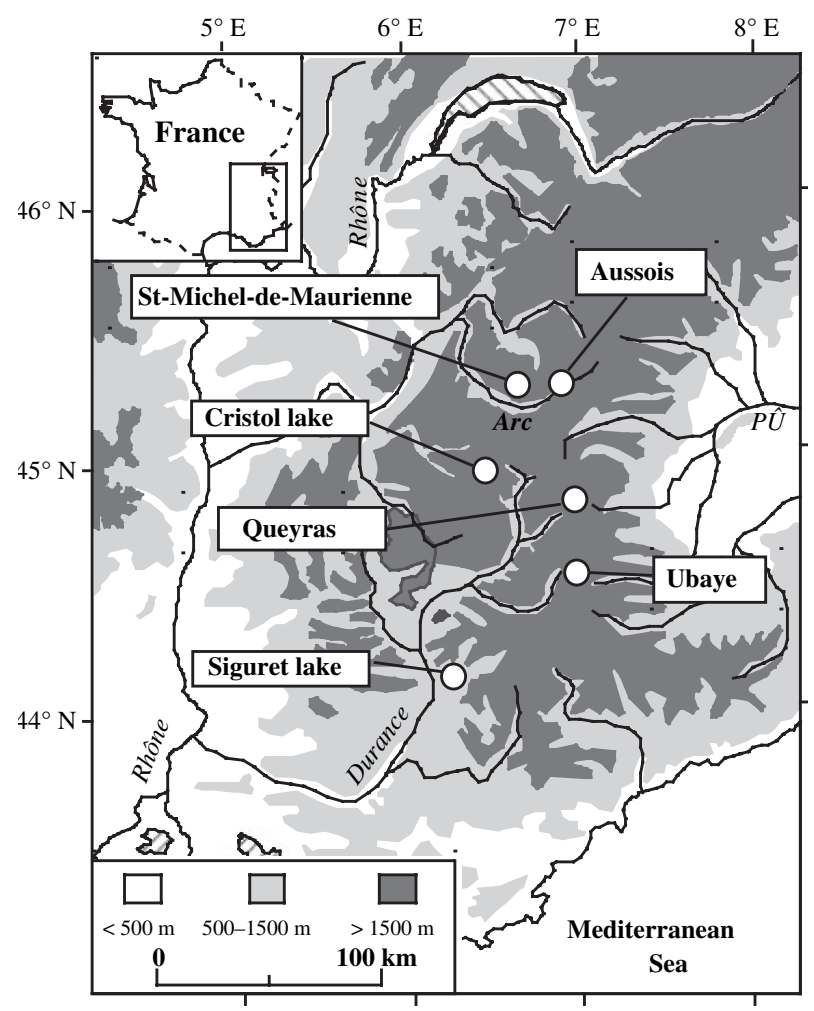

Figure 1 Location of the study (Queyras, Ubaye, Saint-Michel de Maurienne and Aussois) and comparison sites (Siguret and Cristol lakes). 
precipitation amounts to $75 \pm 16 \mathrm{~mm}$, while the mean annual temperature is $5.8 \pm 5.5^{\circ} \mathrm{C}$. Mean temperatures for the coldest (February) and warmest (July) months are -3.0 and $+13.0^{\circ} \mathrm{C}$, respectively. The woody vegetation is composed of woodlands spreading between 1700 and $2400 \mathrm{~m}$ a.s.l., and is dominated by L. decidua, P. cembra and P. uncinata. The understorey is dominated by Rhododendron ferrugineum L., Vaccinium uliginosum L. (mostly on north-facing slopes), Arctostaphylos uvaursi (L.) Spreng. (on south-facing slopes) and Juniperus communis $\mathrm{L}$. The tree line on the north-facing slopes is formed by a mosaic of $L$. decidua woodlands, spreading up to $2400 \mathrm{~m}$ a.s.l. On the south-facing slopes, traditional land use has been devoted mainly to livestock grazing (mostly sheep), resulting in large areas of meadows and heathland slopes, where trees are absent above $2000 \mathrm{~m}$. The upper Ubay Valley $\left(44^{\circ} 36^{\prime} \mathrm{N}\right.$, $6^{\circ} 52^{\prime} \mathrm{E}$ ) is located in the south-east of the Queyras region (Fig. 1). The climate is similar but a little drier than that of the Queyras area. The vegetation is more or less the same, but $P$. cembra is present sporadically.

In the upper Maurienne Valley, two neighbouring sites, separated by $10 \mathrm{~km}$, were studied in the localities of SaintMichel-de-Maurienne $\left(45^{\circ} 15^{\prime} \mathrm{N}, 6^{\circ} 30^{\prime} \mathrm{E}\right)$ and Aussois $\left(45^{\circ} 15^{\prime} \mathrm{N}, 6^{\circ} 45^{\prime} \mathrm{E}\right)$ (Fig. 1). The upper Maurienne Valley is one of the driest of the Alps. The following climate data were recorded at $1360 \mathrm{~m}$ a.s.l. in Saint-Michel and at $1490 \mathrm{~m}$ in Aussois. The mean monthly precipitation amounts to $79 \pm 14 \mathrm{~mm}$ at Saint-Michel-de-Maurienne and $59 \pm 10 \mathrm{~mm}$ at Aussois. The mean annual temperatures are 7.0 and $6.2^{\circ} \mathrm{C}$, respectively; the mean temperatures for the coldest month (January) are -0.7 and $-3.2^{\circ} \mathrm{C}$, and for the warmest month (July) they are 15.0 and $15.2^{\circ} \mathrm{C}$. Needle-leaf trees, including P. uncinata, P. cembra, L. decidua and P. abies, dominate the present-day local vegetation. The understorey consists mostly of Juniperus communis, Vaccinium myrtillus L., V. uliginosum, V. vitis-idaea L., Arctostaphylos uva-ursi, Erica herbacea L. and Rhododendron ferrugineum. On the south-facing slopes, above $2000 \mathrm{~m}$, grazing is frequent between June and early October, and trees are rare. The tree line is located at 2350 and $2400 \mathrm{~m}$ a.s.l. on the south-facing and north-facing slopes, respectively.

\section{MATERIAL AND METHODS}

\section{Sampling}

In total, 37 soil profiles were sampled in the upper Maurienne (23), the upper Ubaye (7) and the Aigue Agnelle (7) valleys, mostly on the south-facing slopes. Soil profiles were dug in trenches down to the bedrock whenever possible. About 10-15 L of dry material was sampled per soil layer of $c$. $20 \mathrm{~cm}$ depth. Charcoal fragments were extracted from the soil matrix using deflocculation and flotation processes with an ascending water current to separate mineral particles from charcoal, followed by watersieving through meshes of 5, 2, 0.8 and $0.4 \mathrm{~mm}$ (Carcaillet \& Thinon, 1996).
Charcoal fragments from 10 travertine sequences were sampled in the Aigue Agnelle (6) and Guil (4) valleys. The quantity of sediment sampled depended on the abundance of charcoal per detrital level. In levels containing charcoal horizons, $10 \mathrm{~L}$ of sediment were extracted, and in levels enclosing dispersed fragments, $30 \mathrm{~L}$ were extracted. The charcoal fragments were recovered in the laboratory by water-sieving the sediment samples through 5 and $2 \mathrm{~mm}$ meshes.

\section{Charcoal identification and analysis}

Charcoal fragments were manually broken and their anatomical characteristics were observed in transversal, tangential and radial sections, under a reflected-light microscope $(\times 100, \times 200$, $\times 500$ and $\times 1000)$. Identifications were made by comparing subfossil fragments with reference collections of charred modern wood species and wood anatomy atlases (e.g. Jacquiot, 1955; Schweingruber, 1990). In each charcoal assemblage, the charcoal mass of P. cembra was expressed as a percentage. This approach allowed the importance of this species to be determined relative to the other burned taxa.

\section{Dating}

Accelerator mass spectrometry (AMS) measurements were used to date charcoal fragments from soil profiles. This technique was necessary because of the low mass of charcoal collected in soils (usually $<10 \mathrm{mg} /$ assemblage), and because soil stratification was not demonstrated (Carcaillet, 2001a,b). Most of the datings were carried out on single fragments of P. cembra. The abundance of charcoal sampled in travertine sequences and the stratification of the deposits generally allowed conventional ${ }^{14} \mathrm{C}$ dating to be carried out on the individual charcoal assemblages containing P. cembra fragments (Ali et al., 2005). All ${ }^{14} \mathrm{C}$ dates were calibrated using the calibration data set INTCAL98 (Stuiver et al., 1998) and the CALIB REV 4.4.2 program (copyright 1986-2004 Stuiver \& Reimer). For ${ }^{14} \mathrm{C}$ dates that have already been published, references are provided (Table 1). Eighteen new datings are presented for the first time in this paper.

\section{RESULTS}

Figure 2 displays the charcoal masses of P. cembra (\%) found within the various charcoal assemblages (169 in total), with increasing altitude. Pinus cembra accounts for between $0 \%$ and $100 \%$ of the identified fragments, indicating a possible patchy distribution of woodlands in space and time between 1700 and $2775 \mathrm{~m}$ a.s.l. Mean values of $38 \%$ (Fig. 2a) and 42\% (Fig. 2b) were obtained for the southern (Queyras region and upper Ubaye Valley) and the northern (Maurienne Valley) areas, respectively. The other fragments belonged to taxa such as Abies alba Mill. (silver fir) Pinus sectio sylvestris, L. decidua, P. abies, Acer opalus Mill. (opalus maple), Acer pseudoplatanus L. (sycamore), Alnus cf. incana (L.) Moench. (grey alder), and 
Table 1 AMS and conventional ${ }^{14} \mathrm{C}$ datings on charcoal fragments of $P$. cembra from the upper Maurienne, upper Ubaye, Aigue Agnelle and Guil valleys

\begin{tabular}{|c|c|c|c|c|c|c|c|}
\hline Profile & Deposit & Altitude (m a.s.l.) & Aspect & Dating & Ages вр & Cal. вр $(2 \delta)^{\star}$ & Reference \\
\hline MAUR 1 & Soil & 2360 & South & AMS & $3415 \pm 85$ & $3470-3870$ & Carcaillet \& Talon (1996) \\
\hline MAUR 1 & Soil & 2360 & South & AMS & $3745 \pm 75$ & $3890-4300$ & Carcaillet \& Talon (1996) \\
\hline MAUR 4 & Soil & 1960 & South & AMS & $4975 \pm 70$ & $5600-5770$ & Carcaillet \& Talon (1996) \\
\hline MAUR 4 & Soil & 1960 & South & AMS & $3885 \pm 70$ & $4140-4450$ & Carcaillet \& Talon (1996) \\
\hline MAUR 6 & Soil & 1770 & South & AMS & $1793 \pm 38$ & $1610-1820$ & AA-62131 \\
\hline MAUR 6 & Soil & 1770 & South & AMS & $4080 \pm 42$ & $4440-4810$ & AA- 62132 \\
\hline MAUR 7 & Soil & 1960 & South & AMS & $5125 \pm 50$ & $5740-5950$ & Carcaillet (1998) \\
\hline MAUR 8 & Soil & 1960 & South & AMS & $3970 \pm 45$ & $4290-4530$ & Carcaillet (1998) \\
\hline MAUR 8 & Soil & 1960 & South & AMS & $4495 \pm 55$ & $4970-5310$ & Carcaillet (1998) \\
\hline MAUR 10 & Soil & 2510 & South & AMS & $3680 \pm 80$ & $3830-4250$ & Carcaillet (1998) \\
\hline MAUR 11 & Soil & 2450 & South & AMS & $3280 \pm 80$ & $3350-3690$ & Carcaillet (1998) \\
\hline MAUR 11 & Soil & 2450 & South & AMS & $3148 \pm 39$ & $3270-3450$ & AA- 62128 \\
\hline MAUR 11 & Soil & 2450 & South & AMS & $3180 \pm 41$ & $3270-3480$ & AA- 62129 \\
\hline MAUR 11 & Soil & 2450 & South & AMS & $3253 \pm 39$ & $3360-3630$ & AA- 62130 \\
\hline MAUR 12 & Soil & 2400 & South & AMS & $3245 \pm 80$ & $3330-3640$ & Carcaillet (1998) \\
\hline AUSS 8 & Soil & 2380 & South & AMS & $3605 \pm 65$ & $3810-4090$ & Carcaillet (1998) \\
\hline AUSS 8 & Soil & 2380 & South & AMS & $4175 \pm 105$ & $4420-4880$ & Carcaillet (1998) \\
\hline AIGUE 2 & Soil & 2670 & South & AMS & $1535 \pm 45$ & $1330-1520$ & Carcaillet \& Talon (1996) \\
\hline AIGUE 2 & Soil & 2670 & South & AMS & $1475 \pm 70$ & $1280-1520$ & Carcaillet \& Talon (1996) \\
\hline AIGUE 7 & Soil & 2400 & South-west & AMS & $3310 \pm 50$ & $3440-3640$ & AA-18001 \\
\hline AIGUE 8 & Soil & 2200 & West & AMS & $5590 \pm 60$ & $6280-6490$ & AA-18003 \\
\hline AIGUE 9 & Soil & 1950 & North & AMS & $5590 \pm 60$ & $6280-6490$ & AA-18004 \\
\hline UBAYE 4 & Soil & 2400 & West & AMS & $2465 \pm 60$ & $2360-2710$ & AA-31364 \\
\hline UBAYE 4 & Soil & 2400 & West & AMS & $5805 \pm 60$ & $6470-6730$ & AA-31365 \\
\hline UBAYE 5 & Soil & 2200 & West & AMS & $3130 \pm 60$ & $3210-3470$ & AA-31367 \\
\hline UBAYE 5 & Soil & 2200 & West & AMS & $3175 \pm 60$ & $3250-3490$ & AA-31366 \\
\hline AIGUE 3 & Travertine & 2280 & South & Conventional & $7605 \pm 140$ & $8110-8720$ & Ali et al. (2002) \\
\hline AIGUE 2 & Travertine & 2280 & South & Conventional & $3540 \pm 100$ & $3570-4090$ & Ali et al. (2005) \\
\hline AIGUE 2 & Travertine & 2280 & South & AMS & $8250 \pm 50$ & $9090-9330$ & Poz-7062 \\
\hline AIGUE 5 & Travertine & 2300 & South & AMS & $7760 \pm 50$ & $8410-8610$ & Poz-7063 \\
\hline AIGUE 5 & Travertine & 2300 & South & AMS & $5620 \pm 45$ & $6310-6490$ & AA-54499 \\
\hline AIGUE 5 & Travertine & 2300 & South & Conventional & $5655 \pm 70$ & $6300-6570$ & Ali et al. (2002) \\
\hline AIGUE 5 & Travertine & 2300 & South & AMS & $6574 \pm 85$ & $7310-7590$ & AA-54499 \\
\hline AIGUE 5 & Travertine & 2300 & South & Conventional & $1785 \pm 75$ & $1540-1870$ & Ali et al. (2002) \\
\hline AIGUE 6 & Travertine & 2320 & South & Conventional & $2915 \pm 70$ & $2870-3260$ & Ali et al. (2002) \\
\hline GUIL 1 & Travertine & 2000 & South & Conventional & $4080 \pm 105$ & $4350-4840$ & Ali et al. (2005) \\
\hline GUIL 1 & Travertine & 2000 & South & Conventional & $3965 \pm 95$ & $4150-4650$ & Ali et al. (2005) \\
\hline GUIL 1 & Travertine & 2000 & South & Conventional & $3165 \pm 150$ & $2950-3720$ & Ali et al. (2005) \\
\hline GUIL 2 & Travertine & 2100 & South & AMS & $7420 \pm 50$ & $8160-8350$ & AA- 54500 \\
\hline GUIL 2 & Travertine & 2100 & South & AMS & $3735 \pm 49$ & $3960-4240$ & AA-53362 \\
\hline
\end{tabular}

${ }^{\star}$ Datings are rounded to the nearest 10 years.

Betula sp. (birch) (Carcaillet, 1996; Talon, 1997; Ali et al., 2005). Most of these taxa were found only at elevations lower than $2000 \mathrm{~m}$ a.s.l.

Chronological changes in the proportion of charcoal fragments in the detrital layers of the travertine sequences show that $P$. cembra woodlands have declined through time in the Queyras area (Fig. 3). Before 7000 cal yr BP, this species accounts for between $80 \%$ and $100 \%$ of the charcoal mass recovered above $2000 \mathrm{~m}$ a.s.l. in this region, suggesting that it was probably a dominant tree at the beginning of the Holocene. From $4000 \mathrm{cal}$ yr BP, however, its abundance appears to have decreased, until, by around
$1700 \mathrm{cal}$ yr BP, it accounts for only $7 \%$ of the charcoal (Fig. 3).

All radiocarbon dates measured for wood charcoal fragments of $P$. cembra are shown in Table 1 . The results reveal that $P$. cembra was present in the French inner Alps during the Holocene between 1700 and $2775 \mathrm{~m}$ a.s.l. In the southern region, the dates reveal that the establishment of $P$. cembra had occurred by $9090-9330 \mathrm{cal} \mathrm{yr} \mathrm{вP} \mathrm{at} \mathrm{the} \mathrm{latest} \mathrm{(Fig.} \mathrm{4a).} \mathrm{Despite}$ the number of datings performed $(n=23)$, we did not obtain any data for the period between $6000 \mathrm{yr}$ BP and $5000 \mathrm{cal} \mathrm{yr} \mathrm{вP.}$ In the Maurienne Valley, arolla pine was established on the south-facing slopes by at least $5740-5960 \mathrm{cal} \mathrm{yr} \mathrm{вP.} \mathrm{Most} \mathrm{of} \mathrm{the}$ 
(a)
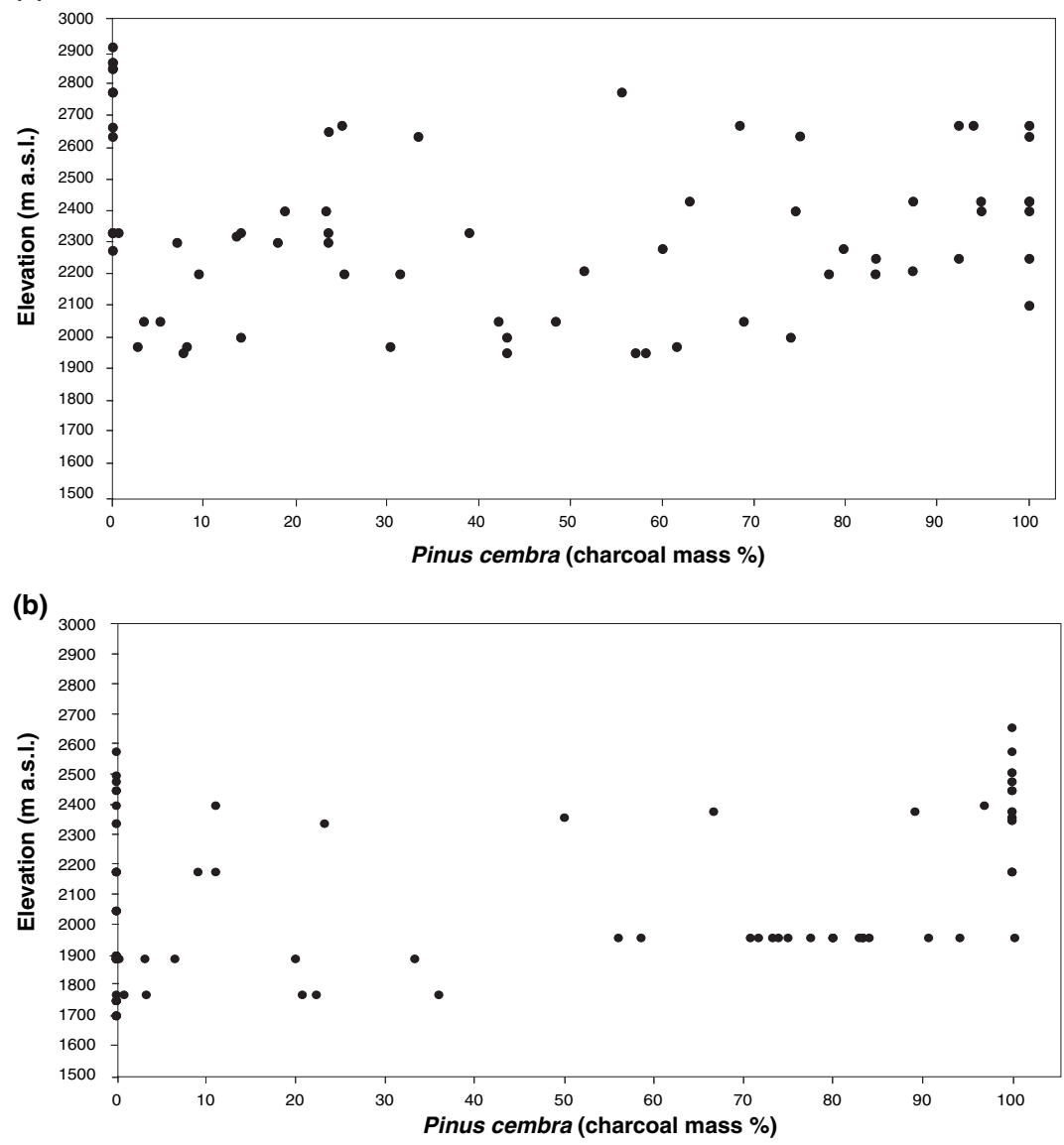

Figure 2 Relative charcoal mass of $P$. cembra (\%) within the various charcoal assemblages with increasing elevation. (a) Southern massifs (Queyras area and upper Ubaye Valley). (b) Upper Maurienne Valley. In total, 169 assemblages were analysed from 40 sequences of soil and travertine.

dates are concentrated during the mid-Holocene, suggesting that $P$. cembra woodlands burned principally between $c .6000$ and 3000 years ago (Fig. 4b).

In the southern region, $P$. cembra charcoal fragments were found up to $2775 \mathrm{~m}$ a.s.l., but radiocarbon dates were obtained only up to $2670 \mathrm{~m}$ a.s.l. (Fig. 4a). The charcoal concentration in the soils decreases drastically with elevation (Carcaillet \& Talon, 2001). Consequently, between 2670 and $2775 \mathrm{~m}$ a.s.l., charcoal fragments collected could not be dated because of their small size and weight $(<1.0 \mathrm{mg})$. Nevertheless, the results clearly indicate that $P$. cembra extended to elevations similar to that of the present-day upper tree line (2400 m a.s.l.) during the major part of the Holocene, but also up to $375 \mathrm{~m}$ higher during an uncertain period (Fig. 4a). In the Maurienne Valley, dates were obtained from materials recovered up to $2510 \mathrm{~m}$ a.s.l. (Fig. 4b). Between $2510 \mathrm{~m}$ a.s.l. and $2660 \mathrm{~m}$ a.s.l., charcoal fragments collected could not be dated for the same reason as in the southern region. The results indicate that $P$. cembra expanded up to $260 \mathrm{~m}$ above the present-day tree line, at least between 4200-3400 cal yr BP (Fig. 4b).

\section{DISCUSSION}

Pinus cembra was a common tree during the Holocene in the subalpine and alpine belts of the inner French Alps (Fig. 2). Its history is associated with the occurrence of fire, owing to the fact that charcoals result from burned vegetation. In the southern French Alps, the earliest pollen grains of P. cembra found so far have been recovered from sediments of the Siguret lake (Durance Valley; $1066 \mathrm{~m}$ a.s.l.), dating to the Alleröd and Late Dryas chronozones (de Beaulieu, 1977). However, concerning the Holocene, synthesis of available pollen studies shows that $P$. cembra forests are not attested in the regional vegetation during the early Holocene. Arolla pine expansion did not occur before c. 6400 cal yr Bp (Coûteaux, 1982, 1984; Fauquette \& Talon, 1995; Nakagawa et al., 2000). This comparison thus reveals a discrepancy, since some of the charcoal fragments of P. cembra dated in Queyras travertine are 2600 years older than the earliest pollen records. It is surprising that $P$. cembra, which was seemingly present during the Alleröd in the study areas, should be so minor a component of the vegetation until $6400 \mathrm{yr}$ BP as to be invisible in the pollen records. Pollen grains of P. cembra associated with L. decidua and Betula have been found in the central Alps continuously since c. 13,000 cal yr BP (Burga, 1988; Heiri et al., 2003). Its expansion in the Queyras area at least c. $9000 \mathrm{cal} \mathrm{yr}$ BP, i.e. 4000 years after its first establishment in the central Alps, is conceivable according to the westward colonization routes proposed by Burga (1988). Moreover, the record of pollen grains of P. cembra in sediments of the Durance Valley, dating to Alleröd and Late Dryas chronozones (de Beaulieu, 1977), suggests possible refuge areas from which this species 

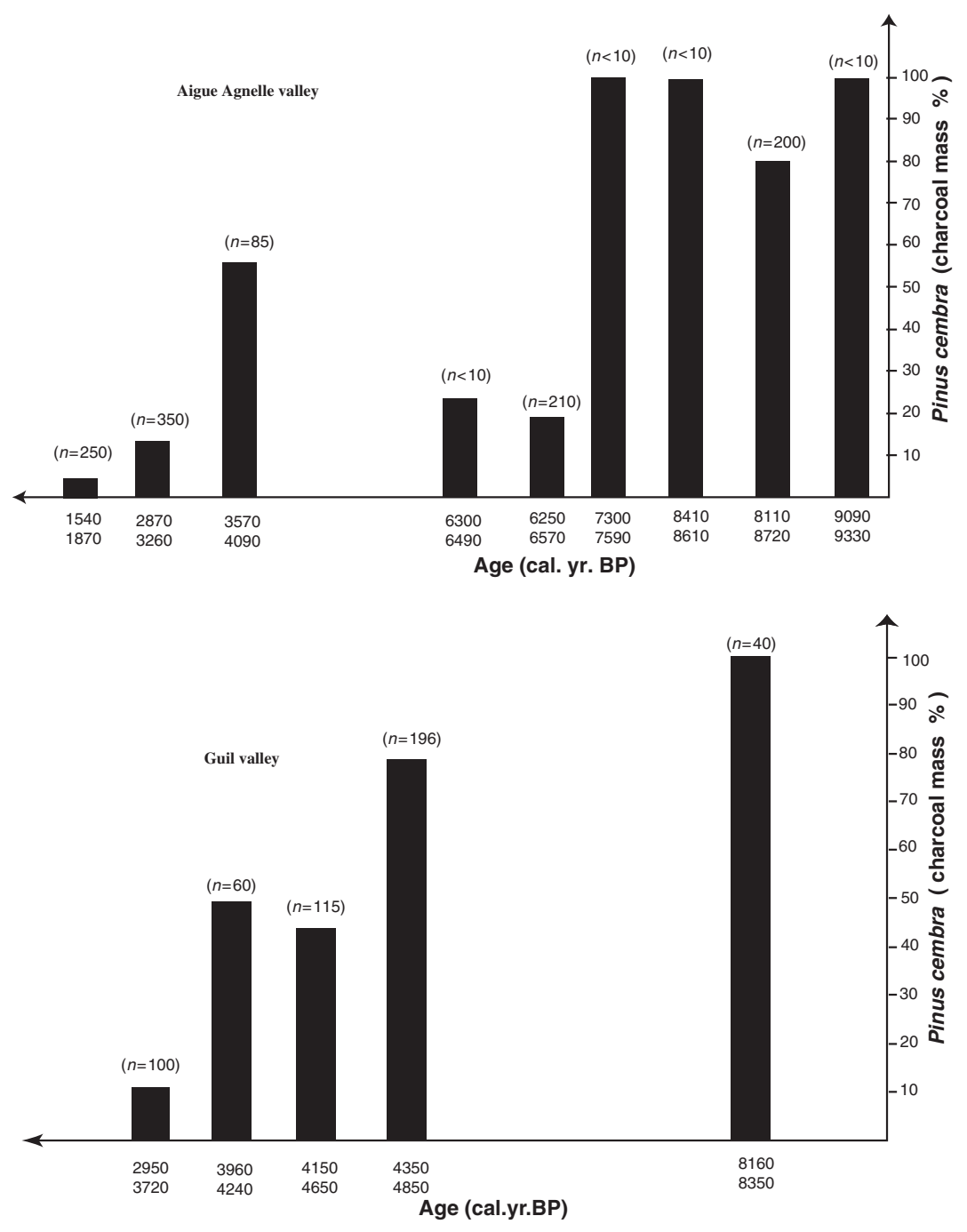

Figure 3 Relative charcoal mass of $P$. cembra (\%) in travertine sequences (Queyras area) through time. $N$ : number of charcoal fragments identified in the assemblage. could have begun its colonization of the southern French Alps after the deglaciation. It is possible that scattered P. cembra individuals migrated quite early in the southern French Alps or have survived since late-glacial times, but their numbers were not sufficient to enable detection in regional pollen records. A similar situation has been proposed to explain the palynological silence in the early Holocene of $P$. abies in the Scandinavian mountains, where pollen grains of spruce are very rare (Segerström \& von Stedingk, 2003), while trunks have been dated from this time in the same area (Kullman, 1996). It is also important to note that it is difficult to distinguish the pollen grains of $P$. cembra from those of other pines (de Beaulieu, 1977; Coûteaux, 1984; Nakagawa et al., 2000). We may assume that $P$. cembra has been underestimated in the pollen records and that it was probably locally important at the beginning of the Holocene in the southern French Alps.

In the Maurienne Valley, arolla pine has been present in the vegetation since at least $c .6000 \mathrm{cal} \mathrm{yr} \mathrm{BP,} \mathrm{while} \mathrm{the} \mathrm{pollen}$ studies indicate that it has been established in the regional vegetation since at least $c .9500$ cal yr вр (Wegmüller, 1977; David, 1995). At this stage of research, no fire events have been recorded before $6000 \mathrm{cal} \mathrm{yr}$ вр in the northern French Alps (Carcaillet, 1998). Consequently, the apparent chronological discrepancy between the pollen and charcoal records concerning the establishment of P. cembra in the Maurienne Valley could be a result of the lack of detected fire events.

\section{Altitudinal and spatial variations of Pinus cembra: climatic or human forcing?}

Today, in the inner French Alps, P. cembra is present in fragmented populations, mostly on the north-facing slopes of valleys and massifs (Contini \& Lavarello, 1982; Rameau et al., 1993; Chas, 1994). In some valleys, such as the Aigue Agnelle and the upper Ubaye and in the Saint-Michel-de-Maurienne locality, P. cembra is absent. Our results reveal that this tree was a common tree at high elevations in all investigated sites during the mid-Holocene. Indeed, the soil and travertine charcoal show that it grew at higher elevations than it does today. The elevational decline of this species was c. $375 \mathrm{~m}$ in the Queyras area and upper Ubaye Valley, and $260 \mathrm{~m}$ in the upper Maurienne Valley. According to the radiocarbon datings 
Figure 4 Distribution of the dates with sampling elevation in southern areas (Queyras area and upper Ubaye Valley) (a) and the upper Maurienne Valley (b). The dotted line corresponds to the highest elevation at which charcoals of $P$. cembra were found (undated specimens).
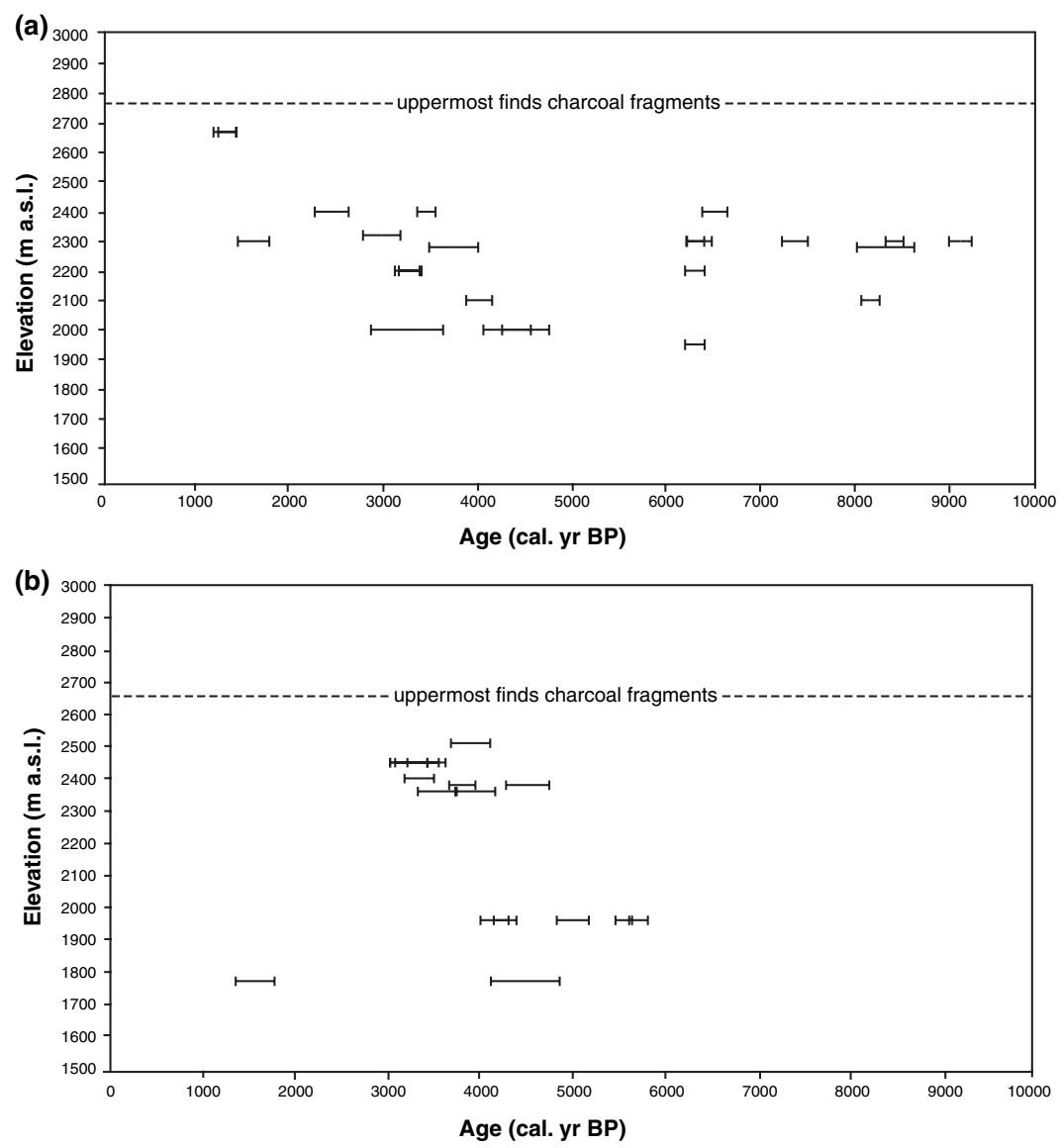

(Table 1) and the regional development of $P$. cembra inferred from pollen analyses (de Beaulieu, 1977; Wegmüller, 1977; David, 1995; Nakagawa et al., 2000), this altitudinal drop may have occurred between $4000 \mathrm{yr}$ вр and $2000 \mathrm{cal} \mathrm{yr} \mathrm{вр.}$

It is important to note that in the French Alps no pollen investigations have been carried out on sites located above $2400 \mathrm{~m}$. Moreover, studies have revealed unfavourable conditions such that the temperature and soil characteristics are limiting factors close to the tree line, and such conditions could cause significant reductions in the pollen production of local trees (Moe, 1998; Hicks, 2001). Consequently, there may be little or no trace of trees growing between 2400 and $2800 \mathrm{~m}$ a.s.l. in the pollen records. Carnelli et al. (2004) have published similar findings from studies in the central Swiss Alps, also based on charcoal from soils, indicating that during the Holocene P. cembra colonized very high altitudes, up to $300 \mathrm{~m}$ above the present local tree line. In reference to our previous studies (Carcaillet et al., 1998; Talon et al., 1998; Carcaillet \& Brun, 2000; Ali et al., 2005) and new results presented in this present paper, we suggest that $P$. cembra may have formed a forested belt between 1700 and $2400 \mathrm{~m}$ a.s.l. in the inner French Alps, along with other woody species, for example P. uncinata, L. decidua, $B$. pendula and B. pubescens. Isolated trees might have occurred at altitudes of up to almost $2800 \mathrm{~m}$ a.s.l.

It is known that climatic variations can induce significant changes in the upper altitudinal limits of tree species (LaM- arche \& Mooney, 1972; LaMarche, 1973; Carrara et al., 1991; Kullman, 1995; Wick \& Tinner, 1997; Seppä \& Birks, 2001). In the Alps, the Holocene has been characterized by small climatic shifts with oscillations of both precipitation and temperature (Haas et al., 1998; Magny et al., 2003). These climatic changes could have induced variations in the altitudinal development of $P$. cembra. However, there is insufficient evidence to conclude that these climatic modifications are responsible for the substantial altitudinal decline of the upper tree line and fragmentation of $P$. cembra woodlands, and sometimes for its local extinctions. Since the mid-Holocene, mankind has become a major ecological factor, profoundly disturbing alpine ecosystems (see, for instance, Burga, 1976; Vorren et al., 1993; Carcaillet, 1998; Talon et al., 1998; Carcaillet \& Brun, 2000; Gobet et al., 2003; Ali et al., 2005). It is very difficult to demonstrate directly that human activities were the main causes of the altitudinal changes of the tree limit and the geographical distribution of $P$. cembra. Nevertheless, the strong differences in woody vegetation between the south- and northfacing slopes within valleys support the hypothesis that local anthropogenic processes have been responsible for changes in the structure of the local vegetation. The diversity of trajectories and the historical pattern of the local extinctions imply a human hand in the causation of $P$. cembra population decline. For instance, the abrupt disappearance of $P$. cembra trunks and pollen in the sediments of Cristol Lake (2200 m a.s.l.) at 
c. 3000 cal yr вр (Nakagawa et al., 2000), coupled with the continued presence of $P$. cembra during this period at nearby sites (Queyras area, present paper), supports this hypothesis.

According to Furrer (1955) and Oeggl (1994), south-facing slopes and higher elevations were primarily deforested by Neolithic populations for agropastoral activities. In the upper Maurienne Valley, the differences in the historical and spatial patterns of fire between Saint-Michel-de-Maurienne and Aussois localities, located $10 \mathrm{~km}$ apart, imply that local processes may have controlled fire ignition during the Holocene in this area (Carcaillet, 1998). Recent archaeological excavations in the Maurienne Valley have shown that local human settlements could be as ancient as the early Neolithic, that is, c. 6000-7000 cal yr вр (Thirault, 2004). In the Southern Alps, human communities were effectively established in the massifs from the Bronze Age onwards (Barge et al., 1995, 1998; Ancel, 1997; Leveau \& Martinez, 2002). Nevertheless, it is possible that human communities might have occupied the southern French Alps episodically during the early Neolithic for transhumance purposes (Breeching \& Riols, 1999; Fedele, 1999). The impact of human practices, with recurrent use of fire, appears to have caused the fragmentation of P. cembra populations and the simultaneous expansion of L. decidua, $P$. abies and $P$. sylvestris woodlands. These changes in vegetation may reflect the poor capacity of $P$. cembra populations to regenerate and expand after fire events and on the resulting bare soils. The other sympatric species are better adapted to recurrent perturbations. However, the intensification of woodland opening without reduction of anthropogenic activities appears to have caused the total regression of woody plants and the establishment of large grassland areas such as those on the south-facing slope of the Aigue Agnelle Valley. Thus, anthropogenic disturbance could have been the main factor affecting the biogeography of $P$. cembra in the inner French Alps since the mid-Holocene. Our results indicate that P. cembra was well established in the past on the south-facing slopes of valleys, and that its present-day scarcity is a consequence of changes in the fire regime and human practices.

\section{CONCLUSIONS}

During the early and the mid-Holocene in the French inner Alps, P. cembra was more widely distributed than it is today. This species colonized high elevations of up to almost $2800 \mathrm{~m}$ a.s.l. In the northern and southern parts, P. cembra shows altitudinal drops of 260 and $375 \mathrm{~m}$, respectively. Arolla pine was abundant on the south-facing slopes of valleys, which are today dominated by grasslands. Human practices since the Neolithic seem to have played a significant role in the biogeography of P. cembra, particularly in respect of its local extinction. However, we cannot rule out the influence of climate on the upper tree-line decrease. Finally, we want to stress the need for further investigations using combined methods such as analyses of charcoal, macro-remains, pollen and travertine imprints, in order to date precisely and understand the nature of the Holocene dynamics of the upper tree line, and the historical biogeography of woody plants in the area.

\section{ACKNOWLEDGEMENTS}

Financial support was provided by the Institut National des Sciences de l'Univers (INSU, France) through the program CONSECOL granted to Christopher Carcaillet, by the Centre National de la Recherche Scientifique (CNRS, France), and by a post-doctoral grant from the Ecole Pratique des Hautes Etudes (Paris, France) to Adam A Ali. This study is part of a program called 'PPF', Populations fractionnées et insulaires (EPHE). We thank Dr John Blackwell (Sees-editing Ltd) for help in improving the English language.

\section{REFERENCES}

Ali, A.A., Guendon, J.-L., Terral, J.-L., Quinif, Y. \& Roiron, P. (2002) Végétation holocène et dynamique d'une forêt subalpine (Queyras, France): étude géomorphologique et paléobotanique de formations travertineuses. Quaternaire, 13, 70-78.

Ali, A.A., Carcaillet, C., Guendon, J.-L., Quinif, Y., Roiron, P. \& Terral, J.-F. (2003) The Early Holocene treeline in the southern inner French Alps: new evidence from plant imprints within travertine. Global Ecology and Biogeography, 12, 411-419.

Ali, A.A., Roiron, P., Guendon, J.-L. \& Terral, J.-F. (2004) Subalpine vegetation dynamics in the southern French Alps during the Holocene: evidence from plant imprints and charcoal preserved in travertine sequences. Arctic, Antarctic and Alpine Research, 36, 42-48.

Ali, A.A., Roiron, P., Guendon, J.-L., Poirier, P. \& Terral, J.-F. (2005) Fire and vegetation pattern changes in the southern inner French Alps (Queyras Massif) during the Holocene: geomorphologic and charcoal analyses of travertine sequences. The Holocene, 15, 149-155.

Ancel, B. (1997) Mines et carrières dans les Hautes-Alpes; apports et évaluation des données du terrain. Proceedings of the 12th International Congress of Speleology (ed. by The Natural History Museum), pp. 245-248. City of Geneva, La Chaux-de-Fonds, Switzerland.

Arquillière, S. (1986) Morphologie, croissance, reproduction végétative de l'épicea (Picea abies (L.) Karst.) dans les Alpes dauphinoises. PhD Thesis, Université Scientifique et Médicale de Grenoble, Grenoble, France.

Barge, H., Ancel, B. \& Rostan, P. (1995) Projet collectif de recherche sur le cuivre. Indices et exploitations minières (Provence et Alpes du Sud). Bilan Scientifique SRA-PACA (Service Régional de l'Archéologie-Provence-Alpes-Coted'Azur). 1995, 315-316.

Barge H., Ancel B., Rostan P., Guendon J.-L. (1998) La mine des Clausis à Saint-Véran (Hautes-Alpes): exploitation et aire de réduction du minerai de cuivre d'époque préhistorique. Actes du Colloque international "Bronze '96" (ed. 
by C. Mordant, M. Pernot, V., Rychner), pp. 71-82. Neuchâtel et Dijon.

de Beaulieu, J.-L. (1977) Contribution pollenanalytique à l'histoire Tardiglaciaire et Holocène de la végétation des Alpes méridionales françaises. $\mathrm{PhD}$ Thesis, Université d'Aix-Marseille 3, Marseille, France.

Birks, H.H. (2003) The importance of plant macrofossils in the reconstruction of late glacial vegetation and climate: examples from Scotland, western Norway, and Minnesota, USA. Quaternary Science Reviews, 22, 453-473.

Birks, H.H. \& Birks, H.J.B. (2000) Future uses of pollen analysis must include plant macrofossils. Journal of Biogeography, 27, 31-35.

Blackford, J.J. (2000) Charcoal fragments in surface samples following a fire and the implications for interpretation of subfossil charcoal data. Palaeogeography, Palaeoclimatology, Palaeoecology, 164, 33-42.

Breeching, A. \& Riols, A. (1999) Une station néolithique d'altitude dans les Alpes du sud: le torrent de Julien à Uvernet-Fours, près de Barcelonnette, Alpes de Haute-Provence. Circulation et identité culturelles alpines à la fin de la préhistoire - Matériaux pour une étude (ed. by A. Breeching), pp. 399-402. Programme CIRCALP 1997-1998, travaux du Centre d'Archéologie Préhistorique de Valence.

Burga, C.A. (1976) Frühe menschliche Spuren in der subalpinen Stufe des Hinterrheins. Geographica Helvetica, 2, 93-96.

Burga, C.A. (1988) Swiss vegetation history during the last 18000 years. The New Phytologist, 110, 581-602.

Camaret, S., Guérin, B. \& Leclerc, D. (1998) Mise en évidence de l'impact du casse-noix moucheté (Nucifraga caryocatactes L.) sur la distribution spatiale de la régénération du pin cembro (Pinus cembra L.). Bulletin de la Société Zoologique Française, 123, 383-392.

Carcaillet, C. (1996) Evolution de l'organisation spatiale des communautés végétales d'altitude depuis 7000 ans BP dans la vallée de la Maurienne (Alpes de Savoie, France): une analyse pédoanthracologique. $\mathrm{PhD}$ Thesis, Université d'Aix-Marseille 3, Marseille, France.

Carcaillet, C. (1998) A spatially precise study of Holocene fire history, climate and human impact within the Maurienne valley, North French Alps. Journal of Ecology, 86, 384-396.

Carcaillet, C. (2001a) Are Holocene wood-charcoal fragments stratified in alpine and subalpine soils? Evidence from the Alps based on AMS ${ }^{14} \mathrm{C}$ dates. The Holocene, 11, 231-242.

Carcaillet, C. (2001b) Soil particles reworking evidences by AMS ${ }^{14} \mathrm{C}$ dating of charcoal. Comptes Rendus de l'Académie des Sciences Paris, Série Sciences de la Terre et des Planètes, $332,21-28$.

Carcaillet, C. \& Brun, J.-J. (2000) Changes in landscape structure in the northwestern Alps over the last 7000 years: lessons from soil charcoal. Journal of Vegetation Science, 11, 705-714.

Carcaillet, C. \& Talon, B. (1996) Stratigraphie et datations de charbons de bois dans les Alpes: quelques aspects ta- phonomiques. Géographie physique et Quaternaire, 50, 233-244.

Carcaillet, C. \& Talon, B. (2001) Soil carbon sequestration by Holocene fires inferred from soil charcoal in the dry French Alps. Arctic, Antarctic, and Alpine Research, 33, 282-288.

Carcaillet, C. \& Thinon, M. (1996) Pedoanthracological contribution to the study of the evolution of the upper treeline in the Maurienne Valley (North French Alps): methodology and preliminary results. Review of Palaeobotany and Palynology, 91, 399-416.

Carcaillet, C., Talon, B. \& Barbero, M. (1998) Pinus cembra et incendies au cours de l'Holocène, $300 \mathrm{~m}$ au-dessus de la limite actuelle des arbres dans les Alpes du nord-ouest. Ecologie, 29, 277-282.

Carnelli, A.L., Theurillat, J.-P., Thinon, M., Vadi, G. \& Talon, B. (2004) Past uppermost tree limit in the Central European Alps (Switzerland) based on soil and soil charcoal. The Holocene, 14, 393-405.

Carrara, P.E., Trimble, D.A. \& Rubin, M. (1991) Holocene treeline fluctuations in the northern San Juan mountains, Colorado, USA, as indicated by radiocarbon-dated conifer wood. Arctic and Alpine Research, 23, 233-246.

Chas, E. (1994) Atlas de la flore des Hautes-Alpes. Conservatoire botanique national de Gap-Charance, Gap, France.

Clark, J.S., Lynch, J., Stocks, B.J. \& Goldammer, J.G. (1998) Relationships between charcoal particles in air sediments in west-central Siberia. The Holocene, 8, 19-29.

Contini, L. \& Lavarello, Y. (1982) Le pin cembro. Répartition, écologie, sylviculture et production. Institut National de la Recherche Agronomique, Paris.

Coûteaux, M. (1982) Recherches pollenanalytiques en Oisans: le plateau de Brande (Alpes d'Huez, Isère, France). Bulletin de Société Royale de Botanique de Belgique, 115, 91-106.

Coûteaux, M. (1984) Présence, datages et signification phytosociologique de macrorestes de Pinus et pollen de Pinus cembra L., à $2050 \mathrm{~m}$ dans le vallon de la Lavey (Massif des Ecrins, Isère, France). Revue de Paléobiologie, 55-62.

Crocq, C. (1990) Le Casse-noix moucheté. Lechevalier-Chabaub, Paris.

David, F. (1995) Vegetation dynamics in the northern French Alps. Historical Biology, 9, 91-106.

Didier, L. (2001) Invasion patterns of European larch and Swiss stone pine in subalpine pastures in the French Alps. Forest Ecology and Management, 145, 67-77.

Fauquette, S. \& Talon, B. (1995) Histoire de la végétation forestière d'un site du Briançonnais: le Lac de Cristol (Hautes-Alpes, France). Comptes Rendus de l'Académie des Sciences Paris (II a), 321, 255-262.

Fedele, F. (1999) Peuplement et circulation des matériaux dans les Alpes occidentales du Mésolithique à l'Age du Bronze. Circulation et identité culturelles alpines à la fin de la préhistoire - Matériaux pour une étude (ed. by A. Breeching), pp. 331-357. Programme CIRCALP 19971998, travaux du Centre d'Archéologie Préhistorique de Valence no. 2, Valence. 
Furrer, E. (1955) Problem um der Rückgang der Arve (Pinus cembra L.) in den Schweiser Alpen. Annales Suisses de Recherches Forestières, 31, 669-705.

Geurts, M.A. \& Watelet, A. (1997) Les travertins de Coal River Springs: physico-chimie des eaux. Géographie physique et Quaternaire, 48, 225-283.

Gobet, E., Tinner, W., Hochuli, P.A., van Leeuwen, J.F.N. \& Ammann, B. (2003) Middle to Late Holocene vegetation history of the upper Engadine (Swiss Alps). The role of Man and fire. Vegetation History and Archaeobotany, 12, 143-163.

Guendon, J.-L., Ali, A.A., Roiron, P., Terral, J.-F., D’Anna, A., Diaz del Olmo, F. \& Baena Escudero, R. 2003. Les travertins de Saint-Antonin: séquence climato-anthropique holocène (Bouches-du-Rhône, France). Karstologia, 41, 1-14.

Haas, J.N., Richoz, I., Tinner, W. \& Wick, L. (1998) Synchronous Holocene climatic oscillations recorded on the Swiss Plateau and at the timberline in the Alps. The Holocene, 8, 301-304.

Heiri, O., Wick, L., van Leeuwen, J.F.N., van der Knaap, W.O. \& Lotter, A.F. (2003) Holocene tree immigration and the chironomid fauna of a small Swiss subalpine lake (Hinterburgsee, $1515 \mathrm{~m}$ asl). Palaeogeography, Palaeoclimatology, Palaeoecology, 189, 35-53.

Hicks, S. (2001) The use of annual arboreal pollen deposition values for delimiting tree-lines in the landscape and exploring models of pollen dispersal. Review of Palaeobotany and Palynology, 117, 1-29.

Holtmeier, F.-K. \& Broll, G. (1992) The influence of tree islands and microtopography on pedoecological conditions in the forest-alpine tundra ecotone on Niwot Ridge, Colorado Front Range, USA. Arctic and Alpine Research, 24, 216-228.

Jackson, S.T., Overpeck, J.T., Webb, T. III, Keatch, S.E. \& Anderson, K.H. (1997) Mapped plant-macrofossil and pollen records of Late Quaternary vegetation change in eastern North America. Quaternary Science Reviews, 16, 1-70.

Jacquiot, C. (1955). Atlas d'anatomie du bois des conifêres. Centre Technique du Bois, Paris.

Kullman, L. (1995) Holocene tree-limit and climate history from the Scandes mountains, Sweden. Ecology, 76, 24902502.

Kullman, L. (1996) Norway spruce present in the Scandes Mountains, Sweden at 8000 BP: new light on Holocene tree spread. Global Ecology and Biogeography Letters, 5, 94-101.

Kullman, L. (2001) The geoecological history of Picea abies in northern Sweden and adjacent parts of Norway. A contrarian hypothesis of postglacial tree immigration patterns. Geoöko, 21, 141-172.

Kullman, L. (2002) Boreal tree taxa in central Scandes during the Late-Glacial: implication for Late-Quaternary forest history. Journal of Biogeography, 29, 1117-1124.

LaMarche, V.C. Jr (1973) Holocene variations inferred from treeline fluctuations in the White mountains, California. Quaternary Research, 3, 632-660.

LaMarche, V.C. Jr \& Mooney, H. (1972) Recent climatic change and development of the Bristlecone pine (Pinus longaeva Bailey) Krummhloz zone, MT. Washington, Nevada. Artic and Alpine Research, 4, 61-72.

Leveau, P. \& Martinez, J.M.P. (2002) Occupation du sol et pastoralisme de la Préhistoire au Moyen Age sur le versant sud des Alpes françaises. Bilan Scientifique SRA-PACA (Service Régional de l'Archéologie-Provence-Alpes-Cote-d'Azur), $58-59$.

Lynch, J.A., Clark, J.S. \& Stocks, B.J. (2004) Charcoal production, dispersal, and deposition from the Fort Providence experimental fire: interpreting fire regimes from charcoal records in boreal forest. Canadian Journal of Forest Research, 34, 1642-1656.

Magnin, F., Guendon, J.-L., Vaudour, J.-L. \& Martin, P. (1991) Les travertins: accumulations carbonatées associées aux systèmes karstiques, séquences sédimentaires et paléoenvironnements quaternaires. Bulletin de la Société Géologique de France, 162, 585-594.

Magny, M., Bégeot, C., Guiot, J., Marguet, A. \& Billaud, Y. (2003) Reconstruction and palaeoclimatic interpretation of mid-Holocene vegetation and lake-level changes at SaintJorioz, lake Annecy, French pre-Alps. The Holocene, 13, 265275.

Mattes, H. (1994) Coevolutional aspects of stone pines and nutcracker. Proceedings of the International Workshop on Subalpine Stone Pines and their Environment: The Status of our Knowledge (ed. by W.C. Schmidt and F.K. Holtmeier), pp. 31-35. Department of Agriculture, Forest Service, Intermountain Research Station, Switzerland.

Moe, D. (1998) Pollen production of Alnus incana at its south Norwegian altitudinal ecotone. Grana, 37, 35-39.

Motta, R. \& Nola, P. (2001) Growth trends and dynamics in sub-alpine forest stands in the Varaita Valley (Piedmont, Italy) and their relationships with human activities and global change. Journal of Vegetation Science, 12, 219230.

Nakagawa, T., Edouard, J.-L. \& de Beaulieu, J.-L. (2000) A scanning electron microscopy (SEM) study of sediments from Lake Cristol, southern French Alps, with special reference to the identification of Pinus cembra and other Alpine Pinus species based on SEM pollen morphology. Review of Palaeobotany and Palynology, 108, 1-15.

Odgaard, B.V. (2001) Palaeoecological perspective on pattern and process in plant diversity and distribution adjustments: a comment on recent developments. Diversity and Distributions, 7, 197-201.

Oeggl, K. (1994) The palynological record of human impact highland zone ecosystems. Highland zone exploitation in Southern Europe. Monografie di Natura Bresciana, 20, 107122.

Ohlson, M. \& Tryterud, E. (2000) Interpretation of charcoal record in forest soils: forest fires and their production and deposition of macroscopic charcoal. The Holocene, 10, 519525.

Payette, S. \& Gagnon, R. (1985) Late Holocene deforestation and tree regeneration in the forest-tundra of Quebec. Nature, 313, 570-572. 
Polunin, O. \& Walters, M. (1986) A guide to the vegetation of Britain and Europe. Oxford University Press, Oxford.

Rameau, J.C., Mansion, D., Dume, G., Timbal, J., Lecointe, A., Dupont, P. \& Keller, R. (1993) Flore forestière française: guide écologique illustré, Vol. 2. Institut pour le Développement Forestier, Paris.

Ritchie, J.C. (1995) Current trends in studies of long-term plant community dynamics. The New Phytologist, 130, 469-494.

Schweingruber, F.H. (1990) Anatomie of European woods. Paul Haupt, Bern.

Segerström, U. \& von Stedingk, H. (2003) Early-Holocene spruce, Picea abies (L.) Karst., in west central Sweden as revealed by pollen analysis. The Holocene, 13, 897-906.

Seppä, H. \& Birks, H.J.B. (2001) July mean temperature and annual precipitation trends during the Holocene in the Fennoscandian tree-line area: pollen-based climate reconstruction. The Holocene, 11, 527-539.

Stuiver, M., Reimer, P.J., Bard, E., Beck, J.-W., Burr, G.S., Hugher, K.A., McCormac, Plich, J. \& Spurk, M. (1998) Extended 14C data base and revised Calib 4.2 14C age calibration programme. Radiocarbon, 40, 1041-1083.

Talon, B. (1997) Evolution des zones supra-forestières des Alpes sud-occidentales au cours de l'Holocène, analyse pédoanthracologique. PhD Thesis, Université d'Aix-Marseille 3, Marseille, France.

Talon, B., Carcaillet, C. \& Thinon, M. (1998) Apport de la pédoanthracologie à l'étude des variations de la limite supérieure des arbres au cours des derniers millénaires dans les Alpes françaises. Géographie physique et Quaternaire, 52, 195-208.

Thirault, E. (2004) Le Rocher du Château au Néolithique. Bessans Jadis et Aujourd'hui, 51, 57-69.

Tranquillini, W. (1979) Physiological ecology of the Alpine timberline. Springer-Verlag, Berlin.

Vorren, K.D., Mørkved, B. \& Bortenschlager, S. (1993) Human impact on the Holocene forest in the Central Alps. Vegetation History and Archaeobotany, 2, 145-156.

Wegmüller, S. (1977) Pollenanalytische Untersuchungen zur spät und postglazialen Vegetationgeschichte der französischen Alpen (Dauphiné). Paul Haupt, Bern.
Wick, L. \& Tinner, W. (1997) Vegetation changes and timberline fluctuations in the central alps as indicators of Holocene climatic oscillations. Arctic and Alpine Research, 29, 445-458.

\section{BIOSKETCHES}

Adam A. Ali is a lecturer at the Ecole Pratique des Hautes Etudes. His main research interests concern the reconstruction of palaeoecosystems based on geobotanical analyses (geomorphology and palaeobotany) of travertine deposits.

Christopher Carcaillet is Professor of Ecology-Palaeoecology at the Ecole Pratique des Hautes Etudes, and the head of the Center of Bio-Archaeology and Ecology. His work concerns the influence of climatic and anthropogenic processes on vegetation patterns in space and time. His main research interest focuses on the palaeoecology of fire in relation to climatic changes and plant diversity dynamics in boreal and mountain ecosystems.

Brigitte Talon is a lecturer in soil science and botany at the University of Aix-Marseille 3. She is researching Holocene vegetation composition and dynamics within the French southern Alps and Mediterranean areas, in relation to human activities. She has wide interests in the field of wood charcoal anatomy and is actively contributing to the development of sequestered wood charcoal analysis in mineral soils.

Paul Roiron is Assistant Professor in Botany and Ecology at the University of Montpellier 2. He works on the history of Neogene and Quaternary vegetation in the Mediterranean Basin, based mainly on fossil leaves.

Jean-Frédéric Terral is Assistant Professor in Plant Biology, Botany and Ecology at the University of Montpellier 2. His main research interests include palaeoenvironmental and palaeoclimatic changes as well as history and evolution of cultivated woody plants. 